\title{
Successful Amplified-Natural-Killer Cell (ANK) Therapy Administered to a Patient with Smoldering Adult T-Cell Leukemia in Acute Crisis
}

\author{
Keisuke Teshigawara $^{1}{ }^{10}$, Sho Nagai $^{2}$, Gaowa Bai ${ }^{3}$ (D), Yuji Okubo ${ }^{1}$, \\ Haorile Chagan-Yasutan ${ }^{3}$ (iD) and Toshio Hattori ${ }^{3, *}$ \\ 1 Higashinotoin Clinic, 338 Enfukuji, Nakagyo, Kyoto 604-8175, Japan; tetetetega@aol.com (K.T.); \\ 1999yuji@gmail.com (Y.O.) \\ 2 Ebino Centro Clinic, 1007-4, Ooazauwae, Ebino, Miyazaki 889-4384, Japan; pw8hcg3m@fine.ocn.ne.jp \\ 3 Department of Health Science and Social Welfare, Kibi International University, 8 Igamachi, \\ Takahashi 716-8508, Japan; gaowabai@kiui.ac.jp (G.B.); haorile@foxmail.com (H.C.-Y.) \\ * Correspondence: hattorit@kiui.ac.jp; Tel.: +81-886-22-9469
}

Received: 22 July 2018; Accepted: 13 August 2018; Published: 14 August 2018

\begin{abstract}
Adult T-cell leukemia (ATL) is an indolent leukemia caused by type 1 human T-cell leukemia virus (HTLV-1). A variety of therapeutic interventions via immunological approaches have been attempted. ATL cells express costimulatory molecules of natural killer (NK) cells, and a new modality-amplified NK (ANK) cell treatment-was administered here to a patient with ATL. A 70-year-old female presenting with ringworm infection received a diagnosis of smoldering ATL in 2004. Monitoring of soluble IL-2 receptors (sIL-2Rs) in the serum showed disease exacerbation in 2007 , associated with the enlargement of lymph nodes and formation of a skin tumor. NK cells were amplified by in vitro cell culture methods. To avoid cytokine release syndrome, $2-5 \times 10^{8}$ cells were administered with each injection. A total of 15 injections from 12 November 2007 to 15 February 2008 were administered to this patient. This case showed drastic downregulation of sIL-2R, resulting in the induction of complete remission, which lasted for $>5$ years. This is the first report of treatment of a patient with ATL using ANK cell therapy. More attempts of this therapy will enhance our insight into the appropriate application of this new therapy to clinically diverse patients.
\end{abstract}

Keywords: ATL; CD3; T cell receptor; HTLV-1; NK cells; therapy

\section{Introduction}

Identification of human T cells by an antithymocyte antibody, in addition to the classical method of rosette formation with sheep red blood cells, became possible in the 1970s. The application of this method led to a preliminary case report of adult T-cell leukemia (ATL), followed by the establishment of this clinical entity in Japan [1,2]. In addition to T-cell properties, their clinical profiles (leukocytosis, lymphadenopathy, hypercalcemia, aberrant lymphocytosis) displayed a very aggressive clinical course. It has been noted that the birth places of these patients were mostly in southwestern Japan, and a subsequent study showed that this region experiences HTLV-1 endemicity $[3,4]$. After the reports of HTLV-1 occurrence, ATL was classified into four clinical subtypes: acute, chronic, lymphoma, and smoldering [5]. It has also been described as adult T-cell leukemia-lymphoma (ATLL) [6].

A surface marker study of ATL cells showed that ATL cells express CD3-T cell receptor (TCR) complexes weakly, which has been determined by measuring the mean fluorescence intensity using flow-cytometric analysis with anti-CD3-TCR monoclonal antibodies (mAbs) [7]. ATL cells can be distinguished by their dim staining of CD3 when compared with the normal CD4 cells in flow-cytometric studies [8]. It was also found that the unique T-cell population "CD4- ${ }^{-} D 8^{-}$ 
double-negative harboring $\alpha \beta \mathrm{TCR}^{\prime \prime}$, which arises from the gastrointestinal tract, is a target of the HTLV-1-induced leukemogenesis [9]. Furthermore, the double-negative ATL cells showed poor expression of the CD3-TCR complex [10]. A recent integrated molecular study of the ATL genome also revealed the frequent alteration in TCR-nuclear factor $\mathrm{KB}$ signaling, which may suggest stimulation of ATL cells through TCR [11].

Stimulation of CD3-TCR causes the activation of ATL cells with phenotypes $\mathrm{CD}^{+}, \mathrm{CD}^{+}, \mathrm{CD}^{-}$, and $\mathrm{CD}_{2} 5^{+}$[12]. Subsequently, numerous cytokines have been reported to be secreted in HTLV-1 infection, such as interleukin-1 $\beta$ (IL-1 $\beta$ ), IL-1 $\alpha$, tumor necrosis factor $\alpha$ (TNF- $\alpha$ ), TNF- $\beta$, and IL-6 [13].

Not only cytokines but also chemokine MIP- $1 \alpha$ has been found to be synthesized by ATL cells. Initially, it was referred to as LD78 because its expression was identified before it was classified as a chemokine [14]. The expression of chemokine receptor CCR4 in ATL has also been noted, and this finding has led to the development of the mAb therapy for ATL, as discussed later [15].

The therapy of patients with ATLL based on their immunological features has been initiated using an anti-CD25 mAb because CD25 is overexpressed in ATL cells. This therapy is based on a humanized monoclonal antibody that blocks IL-2 binding by recognizing the interleukin-2 receptor $\alpha$ chain (CD25). Binding-site saturation on ATL cells in lymph nodes requires the antibody to be at $8 \mathrm{mg} / \mathrm{kg}$. By means of the $\mathrm{mAb}$ as a therapeutic agent, however, only partial responses have been observed in patients with chronic and smoldering ATLL [16]. Recently, anti-CCR4 mAb therapy (mogamulizumab) was used after discovering that $~ 90 \%$ of ATL cells are positive for CCR4 [15]. This therapy, requiring only $1 \mathrm{mg} / \mathrm{kg}$ antibody, has been found to be effective at treating patients with ATLL, who have limited treatment options owing to the intrinsic resistance of ATL cells to conventional chemotherapy [17]. However, treatment with mogamulizumab therapy has often been associated with skin eruptions as an adverse effect. There is a report of a patient with ATL who received a diagnosis of Stevens-Johnson syndrome after this therapy [18]. A case of fatal immune recovery inflammatory syndrome (IRIS) has been associated with this anti-CCR4 mAb therapy, probably occurring due to depletion of regulatory $\mathrm{T}$ cells, which also harbor CCR4 [19]. Recent genetic analysis showed overexpression of the programmed cell death ligand (PD-L1 gene) [20]. Because of a well-known immune suppressor function of PD1-PD-L1 interaction, anti-PD-1 antibodies have been administered to patients with ATLL; however, they lead to rapid disease progression [21]. The Tax oncoprotein activates various cellular and viral genes, including cytokines and their receptors [22]. These cellular genes include costimulatory-signal-related genes (CD80, CD86, and CD137L), which are known to stimulate natural killer (NK) cell activity [23]. The expressed costimulatory antigens stimulate cytotoxic T lymphocytes and natural killer cells $[24,25]$. Therefore, the activated killer cells may eliminate transformed cells in a healthy carrier, and a long latent period until old age is needed for manifestation of the clinical outcome of ATL. It is also known that the percentage of NK cells with the $\mathrm{CD} 16^{+} \mathrm{CD} 56^{+}$phenotype is significantly lower in the HTLV-1-infected healthy carriers [26]. Furthermore, the NK-cell-inhibitory molecule HLA-Class I gene is hypermethylated and silenced in many ATL cells [11]. Therefore, we believe that the ANK cell treatment of ATL is a rational approach.

\section{Case Report}

A 70-year-old female received a diagnosis of high blood pressure. She had a ringworm infection in the whole body since the fall of 2004. Despite consultation and treatment at a clinic, her condition had not improved. Therefore, she was referred to a university hospital for further evaluation, and finally a diagnosis of smoldering ATLL was made because of the presence of an anti-HTLV- 1 antibody and provirus DNA of HTLV-1. Her daughter and husband tested negative for anti-HTLV-1 antibodies. She was treated with a varicella vaccine derivative as an immune adjuvant in a university hospital. Her skin lesions experienced repeated remission and aggravation. Her disease was monitored by measuring soluble IL-2 receptor (sIL-2R) levels. Acute crisis was diagnosed because of the observed elevation in sIL-2R levels, from $1800 \mathrm{U} / \mathrm{mL}$ in April 2007 to 11,000 U/mL in September 2007. She had a significant number of anomalous cells (27\%) in the blood, when analyzed in August 2007 (Figure 1). 
PET showed systemic enlargement of lymph nodes (Figure 2A), and skin lesions were also found (Figure 2B). ANK cell treatment was approved by the ethical committee of the Ebino clinic, and written informed consent was obtained from the patient.

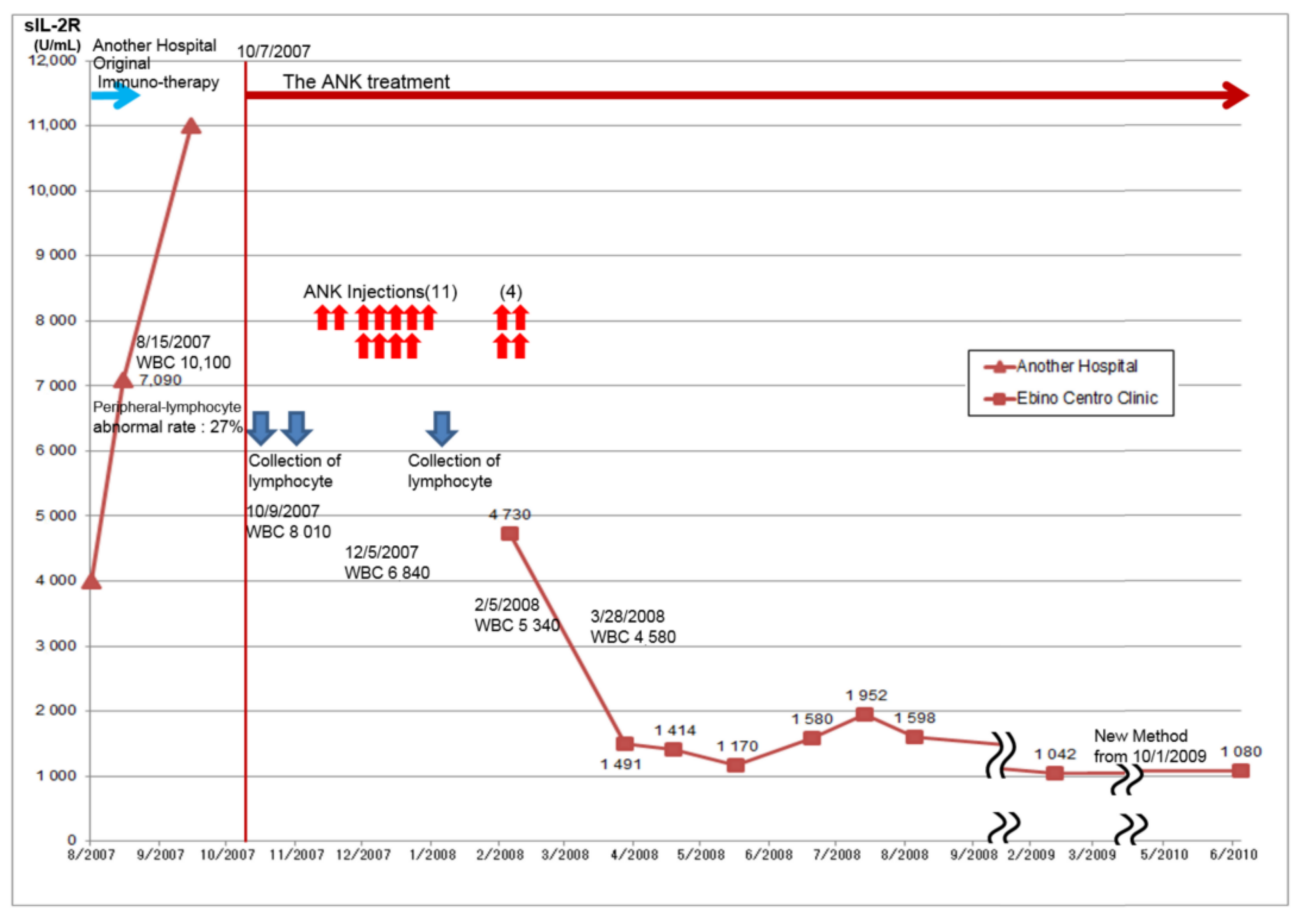

Figure 1. Soluble IL-2 receptor (sIL-2R) levels in the serum of the patient. Due to the gradual increase of the levels, ANK cell treatment was initiated. After repeated injections of ANK cells, sIL-2R levels decreased. The red arrow indicates an injection associated with ANK cell treatment. The blue color indicates venous blood collection for the ANK cell culture. The typical range of sIL-2R was 190-650 U/mL before 1 October 2009, and thereafter shifted to 122-496 U/mL.

A

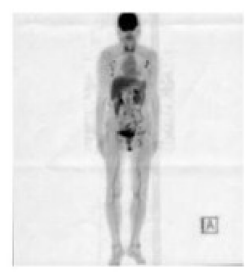

\section{Before the ANK treatment} 9/19/2007

B Early phase of the ANK treatment $12 / 03 / 2007$

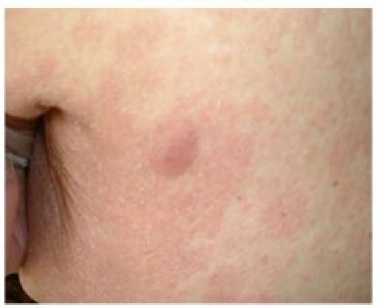

C After the ANK treatment $2 / 21 / 2008$

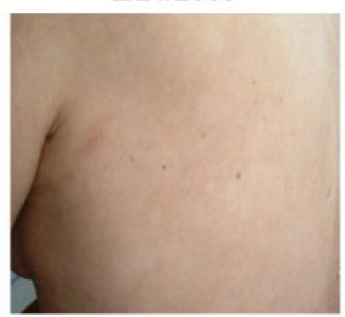

Figure 2. A positron emission tomography-computed tomography (PET-CT) image (before the ANK cell treatment) and skin lesions of the patient. (A) PET-CT revealed the enlargement of multiple lymph nodes before ANK cell treatment; (B) She had a rash and tumors on her whole body in the early phase of ANK cell treatment (3 December 2007); (C) After the repeated administration of ANK cells, she was cured of multiple skin lesions (21 February 2008). 


\subsection{Preparation of ANK Cells}

Her peripheral blood mononuclear cells (PBMCs) were isolated from whole blood by Ficoll (Lymphoprep; Alere Technologies, Oslo, Norway) density gradient centrifugation. PBMCs $\left(5 \times 10^{5}\right.$ to $10^{6} / \mathrm{mL}$ ) were cultured in 50\% AIM (Thermo Fisher Scientific, Waltham, MA, USA ) $/ 50 \%$ KBM502 (Kojin-Bio, Sakado, Japan) containing TU-A (ligands for CD28 and CD137 supplemented with IL-15, Immunopathology Institute, Kyoto, Japan) and 20\% v/v NK cell serum replacement (NKSR, Immunopathology Institute, Kyoto, Japan) supplemented with recombinant human IL-2 (rIL2) (500 U / mL). IL-2 and IL-15 are reported to stimulate NK cells and NK receptor-positive T cells [27], and this modified culture also supports the growth of NK cells. Half volume of the cultured medium was replaced every 2-3 days with a fresh medium. After 2 to 3 weeks, surface marker analysis showed that $50 \%$ to $90 \%$ of the cultured lymphocytes were CD3-negative and CD56-positive, indicating that the majority had the NK phenotype. NK activities were measured as described elsewhere [28]. The average NK activity value of cells from 20 heathy persons (13 males, 7 females, age 20 to 72 years) was $8.9 \%$ at the E:T ratio of 5:1; and it was $87 \%$ for this patient's ANK cells that were cultured for 14 days (Table 1 ). ANK cells were also cytotoxic to NK-resistant Daudi cells.

Table 1. NK activity of fresh lymphocytes from normal healthy individuals and ANK cells from the patient.

\begin{tabular}{lccc}
\hline \multicolumn{2}{c}{ Freshly Prepared Lymphocytes $(\mathbf{n}-\mathbf{2 0})$} & The Cultured Lymphocytes (ANK) \\
\hline NK activity (K562, E:T ratio $=40: 1)$ & $41.5 \%(15.4-73 \%) *$ & & \\
NK activity (K562, E:T ratio $=5: 1)$ & $8.9 \%(0-20.6 \%)$ & NK activity (K562, E:T ratio $=5: 1)$ & $87 \%$ \\
& & NK activity (Daudi, E:T ratio $=5: 1)$ & $73 \%$ \\
\hline
\end{tabular}

* The lowest and highest values of NK activity are shown in parentheses.

\subsection{ANK Cell Treatment}

The cultured lymphocytes were subdivided into multiple cryovials and stored at $-80{ }^{\circ} \mathrm{C}$. Before the ANK cell treatment, the frozen cultured lymphocytes were thawed and cultured in the fresh medium for 5 days. By monitoring NK activity of injected individuals who had cancer, it was found that NK-cell activity decreased 3 to 4 days after a single injection of ANK cells. To maintain NK cell activity, ANK cells were given twice a week.

To avoid cytokine release syndrome, $2-5 \times 10^{8}$ cells were administered per injection. A total of 15 injections from 12 November 2007 to 15 February 2008 were administered to this patient. In response to the treatment, this case showed a drastic decrease in the level of sIL-2R (Figure 1) and disappearance of skin tumors (Figure 2C). The patient has been in complete remission for more than 5 years. Skin lesions were cured at the last administration of ANK cell treatment; thereafter, sIL-2R concentration decreased and became stable at $\sim 1000 \mathrm{U} / \mathrm{mL}$. Hematological and clinical examinations showed no abnormality. No supportive therapy for ATLL was administered and the complete remission had persisted until she died of myocardial infarction on 22 April 2013.

\section{Discussion}

The ANK cell treatment described here specific for tumor cells and poses a low risk of severe damage to the normal immune system. We have been expanding this therapy to other smoldering or chronic lymphoma cases. With this therapy, patients with ATL have not experienced serious adverse effects as seen in anti-CCR4 $[18,19]$ or anti-PD-1 therapy [21]. The high expression of PD-1 on ATLL cells is also reported [29]. Therefore, an anti-PD-1 antibody may inhibit the negative self-regulatory signal through PD-1 and PD-L1 in ATLL cells and induce the proliferation of ATLL cells. In ATLL, PD-L1 may work both as an inhibitor of ATLL cell proliferation and an immune suppressor of a normal immune system. On the contrary, it has been reported that a large number of ANK cells 
kills PD-L1-positive tumor cells [30]. These findings suggest that repeated administration of NK cells including ANK cells relieves the immune suppression through the PD-1-PD-L1 pathway.

Recently, lenalidomide demonstrated a promising antitumor activity against aggressive ATL [31]. Furthermore, lenalidomide may activate NK cells and has synergistic activity with antitumor antibody therapy by increasing antibody-dependent cell-mediated cytotoxicity [32] and indicates the suppression of PD-1 and PD-L1 expression in tumor cells [33]. It would be interesting to see if the synergistic effect of lenalidomide with ANK cell treatment can be observed. Because of the aggressive nature and frequent adverse effects observed with the use of biological agents, as described in the introduction, other new therapies should be explored for treating ATL.

In this case report, the patient with acute ATL was successfully treated by ANK cell administration, and the patient has been well since February 2008. We have treated more than four cases of smoldering or chronic ATL successfully (Sho Nagai, Yuji Okubo et al. manuscript in preparation).

The ANK cell treatment should be evaluated more extensively regarding the general use for patients with cancer or a chronic infectious disease, such as multidrug-resistant tuberculosis, because low NK cell activity denotes accumulation of the bacterial load [34].

We recently showed that Tax induces osteopontin (OPN) expression by transactivating its promoter [35]. OPN is an autocrine and paracrine mediator, interacting with integrin $\alpha \mathrm{v} \beta 3$ or CD44 for transduction of cell-matrix signaling directed to increase motility, invasion, and angiogenesis. Immunohistochemical staining of lymph nodes and skin from patients with ATL by means of anti-OPN antibodies indicates that the expression is weak to moderate in ATL cells but moderate to strong in infiltrating macrophages. A comparison between the level of plasma OPN and clinical data has shown a significant correlation between plasma OPN and performance status, total involved lesion, LDH, and the lymphocyte count $(p<0.01)[36]$.

The anti-OPN mAb, not to human but to mouse OPN, was reported to inhibit the growth of human ATL cells in mice with a transplant because this antibody reacts with fibroblasts, which are involved in supporting tumor growth [37]. Adhesive molecules may work as costimulatory signals for ATL. More research on this mAb for application to ATL therapy is necessary.

In diffuse large B-cell lymphomas, the B-cell receptor signaling mode has been more specifically described as "chronic active", being qualitatively similar to the signaling of antigen-exposed B cells. Furthermore, tumor regression has been achieved by the inhibition of B-cell receptor signals [38]. Attempts should also be made to develop effective inhibitors of TCR in ATL, which are apparently stimulated in vivo.

\section{Conclusions}

We described immunological features of ATL cells and found that ANK cell therapy may be effective as a treatment for ATL. One case with acute crisis of ATL was shown to be successfully treated by this modality. ATL cells have other immunological features such as downregulation of CD3-TCR complexes and expression of matricellular proteins. The development of new immunological therapies involving these molecules is necessary in addition to the ANK cell therapy.

Author Contributions: S.N. treated the patient and contributed to the organization of the clinical data. K.T. and Y.O. performed the lymphocyte culture and its management. T.H. wrote this paper and contributed to the organization of the figures. H.C.-Y. and G.B. contibuted to write a paper.

Funding: This work was in part supported by the Research Program on Emerging and Re-Emerging Infectious Diseases from the Japan Agency for Medical Research and Development (AMED, 965143), and partially supported and by the Japan Society for the Promotion of Science (JSPS) Grants-in-Aid for Scientific Research (KAKENHI), Grant Number JP17H01690.

Conflicts of Interest: The authors declare no conflict of interest. 


\section{References}

1. Yodoi, J.; Takatsuki, K.; Masuda, T. Two cases of T-cell chronic lymphocytic leukemia in Japan. N. Engl. J. Med. 1974, 290, 572-573. [PubMed]

2. Uchiyama, T.; Yodoi, J.; Sagawa, K.; Takatsuki, K.; Uchino, H. Adult T-cell leukemia: Clinical and hematologic features of 16 cases. Blood 1977, 50, 481-492. [CrossRef]

3. Poiesz, B.J.; Ruscetti, F.W.; Gazdar, A.F.; Bunn, P.A.; Minna, J.D.; Gallo, R.C. Detection and isolation of type $C$ retrovirus particles from fresh and cultured lymphocytes of a patient with cutaneous T-cell lymphoma. Proc. Natl. Acad. Sci. USA 1980, 77, 7415-7419. [CrossRef] [PubMed]

4. Hinuma, Y.; Nagata, K.; Hanaoka, M.; Nakai, M.; Matsumoto, T.; Kinoshita, K.I.; Shirakawa, S.; Miyoshi, I. Adult T-cell leukemia: Antigen in an ATL cell line and detection of antibodies to the antigen in human sera. Proc. Natl. Acad. Sci. USA 1981, 78, 6476-6480. [CrossRef] [PubMed]

5. Takatsuki, K.; Yamaguchi, K.; Kawano, F.; Hattori, T.; Nishimura, H.; Tsuda, H.; Sanada, I.; Nakada, K.; Itai, Y. Clinical diversity in adult T-cell leukemia-lymphoma. Cancer Res. 1985, 45, 4644s-4645s. [PubMed]

6. Shimoyama, M.; Minato, K.; Tobinai, K.; Nagai, M.; Setoya, T.; Takenaka, T.; Ishihara, K.; Watanabe, S.; Hoshino, H.; Miwa, M.; et al. Atypical adult T-cell leukemia-lymphoma: Diverse clinical manifestations of adult T-cell leukemia-lymphoma. Jpn. J. Clin. Oncol. 1983, 13 (Suppl. 2), 165-187. [PubMed]

7. Tsuda, H.; Takatsuki, K. Specific decrease in T3 antigen density in adult T-cell leukemia cells: I. Flow microfluorometric analysis. Br. J. Cancer 1984, 50, 843-845. [CrossRef] [PubMed]

8. Foss, F.M.; Aquino, S.L.; Ferry, J.A. Case records of the Massachusetts General Hospital. Weekly clinicopathological exercises. Case 10-2003. A 72-year-old man with rapidly progressive leukemia, rash, and multiorgan failure. N. Engl. J. Med. 2003, 348, 1267-1275. [CrossRef] [PubMed]

9. Hattori, T.; Asou, N.; Suzushima, H.; Takatsuki, K.; Tanaka, K.; Naito, K.; Natori, H.; Oizumi, K. Leukemia of novel gastrointestinal T-lymphocyte population infected with HTLV-I. Lancet 1991, 337, 76-77. [CrossRef]

10. Suzushima, H.; Asou, N.; Nishimura, S.; Nishikawa, K.; Wang, J.-X.; Okubo, T.; Naito, M.; Hattori, T.; Takatsuki, K. Double negative $\left(\mathrm{CD}^{-} \mathrm{CD}^{-}\right) \mathrm{T}$ cells from adult $\mathrm{T}$ cell leukemia patients also have poor expression of the T cell receptor ab/CD3 complex. Blood 1993, 81, 1032-1039. [PubMed]

11. Kataoka, K.; Nagata, Y.; Kitanaka, A.; Shiraishi, Y.; Shimamura, T.; Yasunaga, J.; Totoki, Y.; Chiba, K.; Sato-Otsubo, A.; Nagae, G.; et al. Integrated molecular analysis of adult T cell leukemia/lymphoma. Nat. Genet. 2015, 47, 1304-1315. [CrossRef] [PubMed]

12. Hattori, T.; Uchiyama, T.; Toibana, T.; Takatsuki, K.; Uchino, H. Surface phenotype of Japanese adult T-cell leukemia cells characterized by monoclonal antibodies. Blood 1981, 58, 645-647. [PubMed]

13. Wano, Y.; Hattori, T.; Matsuoka, M.; Takatsuki, K.; Chua, A.O.; Gubler, U.; Greene, W.C. Interleukin 1 gene expression in adult T cell leukemia. J. Clin. Investig. 1987, 80, 911-916. [CrossRef] [PubMed]

14. Yamamura, Y.; Hattori, T.; Obaru, K.; Sakai, K.; Asou, N.; Takatsuki, K.; Ohmoto, Y.; Nomiyama, H.; Shimada, K. Synthesis of a novel cytokine and its gene (LD78) expressions in hematopoietic fresh tumor cells and cell lines. J. Clin. Investig. 1989, 84, 1707-1712. [CrossRef] [PubMed]

15. Ishida, T.; Utsunomiya, A.; Iida, S.; Inagaki, H.; Takatsuka, Y.; Kusumoto, S.; Takeuchi, G.; Shimizu, S.; Ito, M.; Komatsu, H.; et al. Clinical significance of CCR4 expression in adult T-cell leukemia/lymphoma: Its close association with skin involvement and unfavorable outcome. Clin. Cancer Res. 2003, 9, 36253634.

16. Berkowitz, J.L.; Janik, J.E.; Stewart, D.M.; Jaffe, E.S.; Stetler-Stevenson, M.; Shih, J.H.; Fleisher, T.A.; Turner, M.; Urquhart, N.E.; Wharfe, G.H.; et al. Safety, efficacy, and pharmacokinetics/pharmacodynamics of daclizumab (anti-CD25) in patients with adult T-cell leukemia/lymphoma. Clin. Immunol. 2014, 155, 176-187. [CrossRef] [PubMed]

17. Ishida, T.; Joh, T.; Uike, N.; Yamamoto, K.; Utsunomiya, A.; Yoshida, S.; Saburi, Y.; Miyamoto, T.; Takemoto, S.; Suzushima, H.; et al. Defucosylated anti-CCR4 monoclonal antibody (KW-0761) for relapsed adult T-cell leukemia-lymphoma: A multicenter phase II study. J. Clin. Oncol. 2012, 30, 837-842. [CrossRef] [PubMed]

18. Ishida, T.; Ito, A.; Sato, F.; Kusumoto, S.; Iida, S.; Inagaki, H.; Morita, A.; Akinaga, S.; Ueda, R. Syndrome associated with mogamulizumab treatment of adult T-cell leukemia/lymphoma. Cancer Sci. 2013, 104, 647-650. [CrossRef] [PubMed] 
19. Mohammed, T.O.; Chagan-Yasutan, H.; Ashino, Y.; Nakayama, W.; Takahashi, Y.; Shimomura, T.; Fujimoto, T.; Watanabe, Y.; Niki, T.; Suzushima, H.; et al. Galectin 9 as a predictive marker for the onset of immune-related adverse effects associated with anti-CCR4 mAb therapy in patients with adult T cell leukemia. Tohoku J. Exp. Med. 2017, 241, 201-208. [CrossRef] [PubMed]

20. Kataoka, K.; Iwanaga, M.; Yasunaga, J.I.; Nagata, Y.; Kitanaka, A.; Kameda, T.; Chiba, K.; Sato-Otsubo, A.; Sanada, M.; Tanaka, H.; et al. Prognostic relevance of integrated genetic profiling in adult T-cell leukemia/lymphoma. Blood 2018, 131, 215-225. [CrossRef] [PubMed]

21. Ratner, L.; Waldmann, T.A.; Janakiram, M.; Brammer, J.E. Rapid progression of adult T-cell leukemia-lymphoma after PD-1 inhibitor therapy. N. Engl. J. Med. 2018, 378, 1947-1948. [CrossRef] [PubMed]

22. Jeang, K.T. Functional activities of the human T-cell leukemia virus type I Tax oncoprotein: Cellular signaling through NF-kB. Cytokine Growth Factor Rev. 2001, 12, 207-217. [CrossRef]

23. Chambers, B.J.; Salcedo, M.; Ljunggren, H.G. Triggering of natural killer cells by the costimulatory molecule CD80 (B7-1). Immunity 1996, 5, 311-317. [CrossRef]

24. Kurihara, K.; Harashima, N.; Hanabuchi, S.; Masuda, M.; Utsunomiya, A.; Tanosaki, R.; Tomonaga, M.; Ohashi, T.; Hasegawa, A.; Masuda, T.; et al. Potential immunogenicity of adult T cell leukemia cells in vivo. Int. J. Cancer. 2005, 114, 257-267. [CrossRef] [PubMed]

25. Saikh, K.U.; Kissner, T.; Ulrich, R.G. Regulation of HLA-DR and co-stimulatory molecule expression on natural killer T cells by granulocyte-macrophage colony-stimulating factor. Immunology 2002, 106, 363-372. [CrossRef] [PubMed]

26. Prince, H.E.; Jackson, A.L. Normal expression of p55 interleukin 2 receptor (CD25) b lymphocytes from former blood donors seropositive for human T lymphotropic virus. Clin. Immunol. Immunopathol. 1990, 57, 459-464. [CrossRef]

27. Dunne, J.; Lynch, S.; O’Farrelly, C.; Todryk, S.; Hegarty, J.E.; Feighery, C.; Doherty, D.G. Selective expansion and partial activation of human NK cells and NK receptor-positive T cells by IL-2 and IL-15. J. Immunol. 2001, 167, 3129-3138. [CrossRef] [PubMed]

28. Blomberg, K.; Granberg, C.; Hemmilä, I.; Lövgren, T. Europium-labelled target cells in an assay of natural killer cell activity. I. A novel non-radioactive method based on time-resolved fluorescence. J. Immunol. Methods 1986, 86, 225-229. [CrossRef]

29. Shimauchi, T.; Kabashima, K.; Nakashima, D.; Sugita, K.; Yamada, Y.; Hino, R.; Tokura, Y. Augmented expression of programmed death-1 in both neoplastic and non-neoplastic CD41 T-cells in adult T-cell leukemia/lymphoma. Int. J. Cancer 2007, 121, 2585-2590. [CrossRef] [PubMed]

30. Lanuza, P.M.; Vigueras, A.; Olivan, S.; Prats, A.C.; Costas, S.; Llamazares, G.; Sanchez-Martinez, D.; Ayuso, J.M.; Fernandez, L.; Ochoa, I.; et al. Activated human primary NK cells efficiently kill colorectal cancer cells in 3D spheroid cultures irrespectively of the level of PD-L1 expression. OncoImmunology 2018, 7, e1395123. [CrossRef] [PubMed]

31. Ishida, T.; Fujiwara, H.; Nosaka, K.; Taira, N.; Abe, Y.; Imaizumi, Y.; Moriuchi, Y.; Jo, T.; Ishizawa, K.; Tobinai, K.; et al. Multicenter phase II study of lenalidomide in relapsed or recurrent adult T-cell leukemia/lymphoma: ATLL-002. J. Clin. Oncol. 2016, 34, 4086-4093. [CrossRef] [PubMed]

32. Zhang, L.; Qian, Z.; Cai, Z.; Sun, L.; Wang, H.; Bartlett, J.B.; Yi, Q.; Wang, M. Synergistic antitumor effects of lenalidomide and rituximab on mantle cell lymphoma in vitro and in vivo. Am. J. Hematol. 2009, 84, 553-559. [CrossRef] [PubMed]

33. Giuliani, M.; Janji, B.; Berchem, G. Activation of NK cells and disruption of PD-L1/PD-1 axis: Two different ways for lenalidomide to block myeloma progression. Oncotarget 2017, 8, 24031-24044. [CrossRef] [PubMed]

34. Kiran, B.; Cagatay, T.; Clark, P.; Kosar, F.; Cagatay, P.; Yurt, S.; Suzergoz, F.; Gurol, A.O. Can immune parameters be used as predictors to distinguish between pulmonary multidrug-resistant and drug-sensitive tuberculosis? Arch. Med. Sci. 2010, 6, 77-82. [CrossRef] [PubMed]

35. Zhang, J.; Yamada, O.; Matsushita, Y.; Chagan-Yasutan, H.; Hattori, T. Transactivation of human osteopontin promoter by human T cell leukemia virus type 1-encoded Tax protein. Leuk. Res. 2010, 34, 763-768. [CrossRef] [PubMed]

36. Chagan-Yasutan, H.; Tsukasaki, K.; Takahashi, Y.; Oguma, S.; Harigae, H.; Ishii, N.; Zhang, J.; Fukumoto, M.; Hattori, T. Involvement of osteopontin and its signaling molecule CD44 in clinicopathological features of Adult T cell leukemia. Leuk. Res. 2011, 35, 1484-1490. [CrossRef] [PubMed] 
37. Maeda, N.; Ohashi, T.; Chagan-Yasutan, H.; Hattori, T.; Takahashi, Y.; Harigae, H.; Yamada, Y.; Fujii, M.; Maenaka, K.; Uede, T. Osteopontin-integrin interaction as a novel molecular target for antibody-mediated immunotherapy in adult T-cell leukemia. Retrovirology 2015, 12, 99. [CrossRef] [PubMed]

38. Jacobs, L.; Habringer, S.; Slawska, J.; Huber, K.; Hauf, E.; Li, Z.; Refaeli, Y.; Schwaiger, M.; Rudelius, M.; Walch, A. Functional imaging in combination with mutation status aids prediction of response to inhibiting B-cell receptor signaling in lymphoma. Oncotarget 2017, 8, 78917-78929. [CrossRef] [PubMed] 